\title{
Recognition of Designer's role between Designers and Non-designers
}

\author{
Kang, Bum-Kyu \\ Design Department \\ DongSeoUniversity, Jurye-dong Sasanggu, Busan, S. Korea
}

\begin{abstract}
General recognition on the role of a designer has differently changed according to the age and region respectively. This research has clarified general recognition on a designer's role among a designer, experts that designers mainly perform co-work and an ordinary people in a period when the design identity is more confused than any other time. The results of this research are as follows. First, the 13 definitions on a role of a designer in a company were identified through field interview survey by presidents and practical responsible persons in design-specialized companies. Second, it was proved whether there is a difference in recognition on a role of a designer between designers and non-designers. Third, this research divided a group of non-designers into two groups such as a design job-related group mainly performing co-work with designer, and an ordinary people's group that doesn't major design. After that, this research found out the most sympathizing definition on a role of a designer at a company in three groups divided into a designer's group, a design job-related group and an ordinary people's group. The awareness on the role of designer was more objectively regulated three-dimensionally in all aspects of a designers group and a non-designers group. In addition, the findings of recognition difference of each group on a designer's role will help comprehensive understanding on each experts group and an ordinary people. The findings of the research will help in performing co-work of designers and non-designers in design decisionmaking based on understanding of this recognition.
\end{abstract}

Keywords: Recognition of designer's role, Designer's role, Design decision making, Awareness of designer's role

\section{INTRODUCTION}

\subsection{Issue raising}

The question 'when is the start of design?' can have a various kind of answer according to a person. There is a person saying that the start of design had started from the New Stone Age, when people first grind and trim stones for hunting, and there are many claims saying that the start of design is from introduction of the mass-production age after the Industrial Revolution. However, the case saying that the start of modern design is from Bauhaus of Germany who tried to raise masters connecting art to skill, that is the mainstream achieving historical empathy. In this viewpoint, it can be said that the development history of modern design is very short compared to other studies. In spite of such short history, majors of the design field are expanded every year and many designers are acting domestically and overseas, so the number of designers in South Korea recently surpassed one million persons according to the Institute for Education Statistics. It is estimated that more than 2 persons among 100 persons of people are designers. The number of design majors have been reached to 38 thousand persons per every year.(Lee Il-Gyu, 2007)[1]

In addition to quantitative expansion of the number of designers, many research works related to the role of designers

\footnotetext{
*Corresponding author.E-mail : idesign@gdsu.dongseo.ac.kr Manuscript received Sep 15, 2011 ; accepted Oct.08, 2011
}

have been recently undertaken in the design academic world and design industry world. By the way, if there is difference of thinking between a designer and the other decision makers who participate in a decision-making process of design, such as marketers, product planners, sale's responsible person and especially, a president, etc., they will experience difficulty in a decision-making process for the design development. For smooth communication with other experts, understanding on recognition of designer's role in a relative standpoint of other expert group is necessary instead of unilateral and self-oriented thought of designers. In general, ability to understand situations of counterpart in a standpoint of counterpart instead of my standpoint as well as ability capable of viewing the world in an universal viewpoint was named as intellect (Kim EoJun,2008)[2]. For example, R. B. Burns(1979) insisted that the true self-recognition can be achieved when we have the both side understanding that are the 'recognizer or self as a subject(I)' and the called 'a person to be recognized or self as the object(Me)'[3]. In this context, recognition on a designer's role should be understood based on both sides a designers group and non-designers group in order to give an insight of overall designer's role.

\subsection{Purposes of Research}

This work was supported by Dongseo University, "Dongseo Frontier Project" Research Fund of 2010 
The recognition on a designer's role has changed differently according to the age and region. This research has investigated general recognition on a designer's role based on the three groups. These are designers, experts groups that designers mainly perform co-work and non-designers. The aims of the research are as follows.

First, the role of designers at a company was defined through a field survey which was a face to face interview by presidents and practically responsible persons of design-specialized companies. Second, these were investigated that the recognition different of designer's role in a company between designer's group and non-designer's group. Third, this research again divided a non-designers group into two groups. These are a designer job-related group which is performing co-work with designers in the design development process and a nondesigner's group who is an ordinary people that doesn't major design. The purpose of the research is to define the most sympathizing definition of designer's role at a company based on the three groups which were divided into a designer's group, a design job-related group and a non-designer's group.

\subsection{Research methods}

This research conducted a qualitative survey and a quantitative survey. The parallelism of qualitative and quantitative surveys complemented disadvantages of the two survey methods each other. This research undertook an interview survey as a main qualitative research technique and a questionnaire as a quantitative research technique. However, in this research undertook a qualitative research principally because of the below reasons. Firstly, this research issue deals with verbal data that is very diverse and intangible data, which is difficult to quantify. Secondly, there is a need for the grounded theory approach, which is a method for discovering theories, concepts, directly from the data, rather than from priori assumptions, other research, or existing theoretical frameworks (Olson E. M.,1993)[4]. The research progression is largely divided into five stages as follows. First, a face to face interview survey was carried out before plan of a questionnaire which was for investigating of designer's role. Second, more implicit and typical a designer's role was investigated through affinity diagram technique (Michael Brassard \& Diane Ritter) by utilizing 'definition of a designer's role at a company' surveyed in the interview survey [5]. [Example 1] explains about how the affinity diagram technique is used? Third, a recognition survey on 'designer's role at a company' was carried out through a questionnaire of designers, an experts group performing co-work with designers and a non-designers group. At this time, the contents on 'designer's role at a company' which had been surveyed through interview survey by design experts were used as survey items of a questionnaire. Fourth, final research results on 'recognition of designer's role at a company' were defined by analyzing materials collected through a questionnaire survey. Furthermore, the recognition different of the definition of role of design in company among designer's group, an experts and a non-designers group was investigated as a main objective of this research.
Example 1. the affinity diagram technique

It is a creative process rather than logical process.

Steps in constructing an affinity diagram. 1. All members of the group agree on and understand the problem statement. 2. Each member of the group writes down verbal responses to the problem on 3 by 5 cards or post-it notes, one response per card. This is done independently and in silence. (This step will be versioned in this research, that is, findings from fishbone diagrams will be transferred on papers which are not only attachable but can also be put on a board, Also all letters are the same font and the same size,...) 3. The cards are laid on a table or the post-it notes are stuck on a flat surface in no apparent order. 4. The team members then silently move the cards or notes into clusters that appear to share similar ideas. The notes can be moved as many times as is necessary until the group is satisfied with the clusters. A cluster can contain any number of cards even one. Often seven to ten clusters will come out of this activity. 5. The group then clarifies and discusses the relationship between the items and assigns a title for the cluster. Many times one of the cards within the cluster will serve as a title for the entire cluster, if not, develop one and place it over the cluster. If there are any items that fell into a miscellaneous cluster, see if they now fit one of the designated clusters

\section{INTERVIEW SURVEY AND SURVEY RESULTS}

\subsection{Description of Interview Survey Method and Survey Process}

This research carried out interview survey on 'role of a designer' with ten presidents who are currently managing a design-specialized company and seven incumbent professors of design colleges in Universities for more empirical research. Its survey period and method are as follows.

- Survey Method: A face to face interview survey was conducted by a researcher.

- Survey Period: June-July, 2010 (around two months)

- Interviewees: Presidents of design-specialized companies and full-time professors of design colleges.

Qualitative research results that the present researcher obtained from the interview survey process are as follows. Most interviewees were limited to presidents of design-specialized companies and persons acting as incumbent professors of design colleges, who have activity career of more than 10 years as a designer. But persons easily answering a question like 'Could you tell me what the designer's role is?' were only 4 persons and 11 persons don't immediately answer and replied after around 1-3 minutes. And 2 persons gave an additional answer through e-mail after the interview was finished. It is predicted that this result was caused by difficulty of a definition on a designer's role and that they don't deeply think recognition on a designer's role of the person oneself.

\subsection{Results of Interview Survey}

Seventeen interviewees gave a total of 48 opinions on 'a role of a designer at a company'. Contents of definition a designer's 
role obtained by interview survey included similar meaning or duplicated contents. Accordingly, the duplicated contents with a similar meaning were simplified through affinity diagram technique.(Michael Brassard \& Diane Ritter,1994)[6] A total of five persons' team consisting of two incumbent professors in the design department, one representative of a designspecialized company and two researchers at a design graduate school proceeded the affinity diagram technique. As a result, a total of thirteen definitions on a design's role could be deduced respectively. The contents of the result can be confirmed from the contents of the multiple response analysis on the definition of a designer's role at a company of 'Table 2'.

\section{QUESTIONNAIRE SURVEY AND SURVEY RESULTS}

\subsection{Questionnaire Survey Method}

This research conducted a questionnaire survey to investigate a recognition difference of designer's role between a designers group and a non-designers group. This is to mutually complement disadvantages of each research survey by running parallel with interview survey as a qualitative survey and questionnaire survey as a quantitative survey of this research. The questions of a questionnaire were largely composed into four parts. First, it is questions on personal information about occupation and title, etc. of questionnaire's respondents. Second, it is composed of questions asking respondents' consensus on a role of a designer at a company. For research on recognition of designer's role, the research surveyed and analyzed the questionnaire survey after dividing it into a designers group and a non-designers group. More detailed survey and analysis were progressed again by dividing a non-designers group into a designer's job-related group which is performing decision making and co-work closely with designers and an ordinary people as a non-designer group. According to mention in books of Hopkins D. S.[7] Rachel Cooper \& Mike Press(1995)[8] Walsh V., Roy R., Bruce M. and Potter S,(1992)[9], Engineers, sales and marketing are being pointed out as a typical job group participating in the decision making of design development process. Therefore, the questionnaire survey was carried out focused on the above three job groups which are job groups of participants in decision making of design development. In case of a designers group, the questionnaire was conducted directly in a dinner event organized by design companies association. On the other hand, some questionnaires were received by mail after asking on the phone and received a questionnaire from some persons while visiting them directly. In case of a group performing co-work with designers, a questionnaire survey was carried out by delivering a questionnaire to persons participating in decision making of design such as a president, engineers, sales, and marketing department of the designspecialized companies that were investigated. A direct visit and mail survey were carried out as a delivery method of a questionnaire. In case of an ordinary people group as a nondesigner, the questionnaire survey was carried out to common housewives and some college students who are not design majors through a visit.

\subsection{Questionnaire Survey Results}

\subsubsection{Characteristics of Research results}

This research has progressed three-dimensional survey with the target of designers, designer job-related persons and nondesigners to find out "general recognition on designer's role in the company". For analysis of the research, a total of 200 copies of questionnaire were distributed and 155 copies of questionnaire were collected. Among them, 129 copies were used for analysis after excluding 26 copies of insincere respondents such as the cases that the department content is not written or there are unanswered questions or an answer is not coincident at duplicated question items. Among them, designers were 35 persons, and there were 35 designer job-related persons who are consisted of presidents of design companies, mangers of marketing and planning departments, sales department and engineering department, and non-designers were 59 persons. In addition, in case of business types of surveyed companies, the manufacturing industry was the highest $38.0 \%$ and the design-specialized companies' group was followed in the order. In case of title, others were $56.6 \%$, and team leaders were $13.2 \%$, and title was occupied in the order of representatives and directors. Working experience of 14 years showed the most $44.2 \%$, and was in the order of 5-8 years and 9-12 years.

Table 1. shows characteristics of respondents.

\begin{tabular}{|c|c|c|c|}
\hline & Division & Frequency & Percent \\
\hline \multirow{3}{*}{ Group } & Designer & 3 & 27.1 \\
\hline & $\begin{array}{c}\text { Designer Job-related } \\
\text { Persons }\end{array}$ & 35 & 27.1 \\
\hline & An ordinary people & 59 & 45.7 \\
\hline \multirow{5}{*}{$\begin{array}{l}\text { Company's } \\
\text { business type }\end{array}$} & $\begin{array}{c}\text { Design-specialized } \\
\text { Company }\end{array}$ & 26 & 20.2 \\
\hline & $\begin{array}{l}\text { Manufacturing } \\
\text { Business }\end{array}$ & 49 & 38.0 \\
\hline & Distribution Business & 10 & 7.8 \\
\hline & Service Business & 11 & 8.5 \\
\hline & Others & 33 & 25.6 \\
\hline \multirow{6}{*}{ Title } & Representative & 13 & 10.1 \\
\hline & Director & 11 & 8.5 \\
\hline & Department Manager & 8 & 6.2 \\
\hline & Section Chief & 7 & 5.4 \\
\hline & Team Leader & 17 & 13.2 \\
\hline & Others & 73 & 56.6 \\
\hline \multirow[t]{6}{*}{ Working years } & $1-4$ years & 57 & 44.2 \\
\hline & $5-8$ years & 27 & 20.9 \\
\hline & $9-12$ years & 14 & 10.9 \\
\hline & $13-16$ years & 6 & 4.7 \\
\hline & $17-20$ years & 7 & 5.4 \\
\hline & More than 21 years & 3 & 2.3 \\
\hline
\end{tabular}




\begin{tabular}{|c|c|c|c|} 
& No Response & 15 & 11.6 \\
\hline & Total & 129 & 100.0 \\
\hline
\end{tabular}

3.2.2 Sympathy Level and Recognition Difference in the Definition of Designer's Role by Groups

If analysis results of each group on sympathy order of role definition of corporate designers are viewed, a designer group is giving the highest grade to "a medium role connecting companies to consumers", which is Definition No. 3 and "a role leading culture", which is Definition No. 7. And a designer jobrelated person group and non-designer group gave the highest grade to "a role of creating vision of a company through product design". The table 2 is overall showing a sympathy level on role definition of designers at a company according to each group with figures.

Table 2. Sympathy level on definition of designer's role at a company according to a group

\begin{tabular}{|c|c|c|c|c|}
\hline Definition & $\begin{array}{c}\text { Designer } \\
\text { Group }\end{array}$ & $\begin{array}{c}\text { Designer- } \\
\text { related } \\
\text { Group }\end{array}$ & $\begin{array}{c}\text { An } \\
\text { ordinary } \\
\text { people's } \\
\text { Group }\end{array}$ & total \\
\hline $\begin{array}{l}\text { 1.Role making } \\
\text { appearance } \\
\text { attractively }\end{array}$ & $\begin{array}{c}11 \\
(10.5)\end{array}$ & $\begin{array}{c}9 \\
(8.6)\end{array}$ & $7(4)$ & $\begin{array}{l}27 \\
(7)\end{array}$ \\
\hline $\begin{array}{l}\text { 2. Role } \\
\text { proposing } \\
\text { 'what will we } \\
\text { make?' and } \\
\text { innovating it }\end{array}$ & $9(8.6)$ & $8(7.6)$ & $\begin{array}{c}19 \\
(10.7)\end{array}$ & $\begin{array}{c}36 \\
(9.3)\end{array}$ \\
\hline $\begin{array}{l}3 \text {. Role of } \\
\text { medium } \\
\text { connecting a } \\
\text { company to } \\
\text { consumers }\end{array}$ & $\begin{array}{c}13 \\
(12.4)\end{array}$ & $\begin{array}{c}10 \\
(9.5)\end{array}$ & $\begin{array}{c}15 \\
(8.5)\end{array}$ & $\begin{array}{c}38 \\
(9.8)\end{array}$ \\
\hline $\begin{array}{l}\text { 4. Role of sales } \\
\text { promotion to } \\
\text { make sale well } \\
\text { achieved }\end{array}$ & $6(5.7)$ & $\begin{array}{c}10 \\
(9.5)\end{array}$ & $\begin{array}{c}13 \\
(7.3)\end{array}$ & $\begin{array}{c}29 \\
(7.5)\end{array}$ \\
\hline $\begin{array}{l}\text { 5. Role of } \\
\text { making or } \\
\text { changing of an } \\
\text { image of a } \\
\text { company }\end{array}$ & $\begin{array}{c}5 \\
(4.8)\end{array}$ & $\begin{array}{c}12 \\
(11.4)\end{array}$ & $\begin{array}{c}20 \\
(11.3)\end{array}$ & $\begin{array}{c}37 \\
(9.6)\end{array}$ \\
\hline $\begin{array}{l}6 . \text { Role } \\
\text { creating a new } \\
\text { value based on } \\
\text { capacity of a } \\
\text { company }\end{array}$ & $\begin{array}{c}12 \\
(11.4)\end{array}$ & $\begin{array}{c}12 \\
(11.4)\end{array}$ & $\begin{array}{c}22 \\
(12.4)\end{array}$ & $\begin{array}{c}46 \\
(11.9)\end{array}$ \\
\hline $\begin{array}{l}\text { 7. Role leading } \\
\text { culture }\end{array}$ & $\begin{array}{c}13 \\
(12.4)\end{array}$ & $4(3.8)$ & $\begin{array}{c}17 \\
(9.6) \\
\end{array}$ & $\begin{array}{c}34 \\
(8.8)\end{array}$ \\
\hline $\begin{array}{l}\text { 8. Role } \\
\text { performing } \\
\text { cost savings } \\
\text { effectively at a }\end{array}$ & $8(7.6)$ & $4(3.8)$ & $7(4)$ & $\begin{array}{c}19 \\
(4.9)\end{array}$ \\
\hline
\end{tabular}

\begin{tabular}{|c|c|c|c|c|}
\hline $\begin{array}{l}\text { company } \\
\text { standpoint }\end{array}$ & & & & \\
\hline $\begin{array}{l}\text { 9. Role } \\
\text { creating vision } \\
\text { of a company } \\
\text { through } \\
\text { product design }\end{array}$ & $10(9.5)$ & $\begin{array}{c}13 \\
(12.4)\end{array}$ & $\begin{array}{c}24 \\
(13.6)\end{array}$ & $\begin{array}{c}47 \\
(12.1)\end{array}$ \\
\hline $\begin{array}{l}10 . \text { Role } \\
\text { capable of } \\
\text { adjusting } \\
\text { opinions with } \\
\text { other group }\end{array}$ & $2(1.9)$ & $0(0)$ & $4(2.3)$ & $6(1.6)$ \\
\hline $\begin{array}{l}\text { 11. Role } \\
\text { satisfying } \\
\text { emotion } \\
\text { through } \\
\text { products }\end{array}$ & $7(6.7)$ & $\begin{array}{c}11 \\
(10.5)\end{array}$ & $\begin{array}{c}13 \\
(7.3)\end{array}$ & $31(8)$ \\
\hline $\begin{array}{l}\text { 12. Role } \\
\text { standardizing } \\
\text { ideas }\end{array}$ & $7(6.7)$ & $7(6.7)$ & $\begin{array}{c}10 \\
(5.6)\end{array}$ & $\begin{array}{c}24 \\
(6.2)\end{array}$ \\
\hline $\begin{array}{l}\text { 13. Role } \\
\text { improving } \\
\text { quality }\end{array}$ & $2(1.9)$ & $5(4.8)$ & $6(3.4)$ & $\begin{array}{c}13 \\
(3.4)\end{array}$ \\
\hline total & $\begin{array}{c}105 \\
(100)\end{array}$ & $\begin{array}{c}105 \\
(100)\end{array}$ & $\begin{array}{c}177 \\
(100)\end{array}$ & $\begin{array}{c}387 \\
(100)\end{array}$ \\
\hline
\end{tabular}

The difference in "definition of a designer's role at a company' between the groups was found out in detail through statistical analysis in the above difference analysis. First, the difference between a designer-related person group and a non-designer group is the same as in the table 3 . As a result of analysis, it appeared that value is 7.364 and $p$ value is 0.769 in test statistic and it is not statistically significant within $5 \%$ of a significance level. Namely, it can be known that there is no difference in 'definition of a designer's role at a company' between a nondesigner group and a design-related person group.

Table 3. Difference analysis of 'recognition on designer's role' between a group of designer-related persons and an ordinary people

\begin{tabular}{|l|c|l|c|}
\hline Definition & $\begin{array}{l}\text { Designer- } \\
\text { related } \\
\text { Group }\end{array}$ & $\begin{array}{l}\text { An } \\
\text { ordinary } \\
\text { people }\end{array}$ & total \\
\hline $\begin{array}{l}\text { 1.Role making } \\
\text { appearance attractively }\end{array}$ & $0(0)$ & $0(0)$ & $0(0)$ \\
\hline $\begin{array}{l}\text { 2 Role proposing 'what } \\
\text { will we make?' and } \\
\text { innovating it }\end{array}$ & $3(8.6)$ & $5(8.5)$ & $8(8.5)$ \\
\hline $\begin{array}{l}\text { 3. Role of medium } \\
\text { connecting a company } \\
\text { to consumers }\end{array}$ & $4(11.4)$ & $3(5.1)$ & $7(7.4)$ \\
\hline $\begin{array}{l}\text { 4. Role of sales } \\
\text { promotion to make sale }\end{array}$ & $3(8.6)$ & $6(10.2)$ & $9(9.6)$ \\
\hline
\end{tabular}




\begin{tabular}{|l|c|c|c|}
\hline well achieved & & & \\
\hline $\begin{array}{l}\text { 5. Role of making or } \\
\text { changing of an image of } \\
\text { a company }\end{array}$ & $5(14.3)$ & $3(5.1)$ & $8(8.5)$ \\
\hline $\begin{array}{l}\text { 6. Role creating a new } \\
\text { value based on capacity } \\
\text { of a company }\end{array}$ & $8(22.9)$ & $11(18.6)$ & $19(20.2)$ \\
\hline 7. Role leading culture & $2(5.7)$ & $3(5.1)$ & $5(5.3)$ \\
\hline $\begin{array}{l}\text { 8. Role performing cost } \\
\text { savings effectively at a } \\
\text { company standpoint }\end{array}$ & $0(0)$ & $3(5.1)$ & $3(3.2)$ \\
\hline $\begin{array}{l}\text { 9. Role creating vision } \\
\text { of a company through } \\
\text { product design }\end{array}$ & $4(11.4)$ & $9(15.3)$ & $13(13.8)$ \\
\hline $\begin{array}{l}\text { 10. Role capable of } \\
\text { adjusting opinions with } \\
\text { other group }\end{array}$ & $0(0)$ & $1(1.7)$ & $1(1.1)$ \\
\hline $\begin{array}{l}\text { 11. Role satisfying } \\
\text { emotion through } \\
\text { products }\end{array}$ & $3(8.6)$ & $8(13.6)$ & $11(11.7)$ \\
\hline $\begin{array}{l}\text { 12. Role standardizing } \\
\text { ideas }\end{array}$ & $1(2.9)$ & $4(6.8)$ & $5(5.3)$ \\
\hline $\begin{array}{l}\text { 13. Role improving } \\
\text { quality }\end{array}$ & $2(5.7)$ & $3(5.1)$ & $5(5.3)$ \\
\hline total & $35(100)$ & $59(100)$ & $94(100)$ \\
\hline Test Statistic & $x^{2}=7.364, \mathrm{p}=0.769$ & \\
\hline
\end{tabular}

The table 4 is results of awareness difference in "definition of a designer's role at a company' between designers and nondesigners. As a result, it appeared that value is 27.342 and $\mathrm{p}$ value is 0.007 in test statistic and there is significant group difference within $5 \%$ of a significance level, and it appeared that there is a difference in 'definition of a designer's role at a company' between a designer group and a non-designer group. As a result, the recognition difference between each group in "definition of a designer's role at a company' is as follows. A designer group showed that "a role making appearance attractively" which is Definition No.1 and "a medium role connecting companies to consumers", which is Definition No. 3 are the most sympathizing designer's role definition. Namely, the two items can be understood as more sympathized definitions of a role of a designer by a designer group then a non-designer group. On the other hand, it was surveyed that a non-designer group is more recognizing "a role creating a new value based on capacity of a company" which is Definition No. 6 , as a role of designers than a designer group.

Table 4. Difference analysis on recognition of designer's role between a designer group and a non-designer group

\begin{tabular}{|l|l|l|l|}
\hline Definition & $\begin{array}{l}\text { Designer } \\
\text { Group }\end{array}$ & $\begin{array}{l}\text { Non- } \\
\text { Designer } \\
\text { Group }\end{array}$ & total \\
\hline
\end{tabular}

\begin{tabular}{|c|c|c|c|}
\hline $\begin{array}{l}\text { 1.Role making } \\
\text { appearance attractively }\end{array}$ & $\begin{array}{c}6 \\
(17.1)\end{array}$ & $0(0)$ & $6(4.7)$ \\
\hline $\begin{array}{l}2 \text { Role proposing 'what } \\
\text { will we make?' and } \\
\text { innovating it }\end{array}$ & $2(5.7)$ & $8(8.5)$ & $\begin{array}{c}10 \\
(7.8)\end{array}$ \\
\hline $\begin{array}{l}\text { 3. Role of medium } \\
\text { connecting a company to } \\
\text { consumers }\end{array}$ & $\begin{array}{c}6 \\
(17.1)\end{array}$ & $7(7.4)$ & $\begin{array}{c}13 \\
(10.1)\end{array}$ \\
\hline $\begin{array}{l}\text { 4. Role of sales } \\
\text { promotion to make sale } \\
\text { well achieved }\end{array}$ & $2(5.7)$ & $9(9.6)$ & $\begin{array}{c}11 \\
(8.5)\end{array}$ \\
\hline $\begin{array}{l}\text { 5. Role of making or } \\
\text { changing of an image of } \\
\text { a company }\end{array}$ & $2(5.7)$ & $8(8.5)$ & $\begin{array}{c}10 \\
(7.8)\end{array}$ \\
\hline $\begin{array}{l}\text { 6. Role creating a new } \\
\text { value based on capacity } \\
\text { of a company }\end{array}$ & $\begin{array}{c}5 \\
(14.3)\end{array}$ & $\begin{array}{c}19 \\
(20.2)\end{array}$ & $\begin{array}{c}24 \\
(18.6)\end{array}$ \\
\hline 7. Role leading culture & $\begin{array}{c}4 \\
(11.4)\end{array}$ & $5(5.3)$ & $9(7)$ \\
\hline $\begin{array}{l}\text { 8. Role performing cost } \\
\text { savings effectively at a } \\
\text { company standpoint }\end{array}$ & $0(0)$ & $3(3.2)$ & $3(2.3)$ \\
\hline $\begin{array}{l}\text { 9. Role creating vision of } \\
\text { a company through } \\
\text { product design }\end{array}$ & $\begin{array}{c}4 \\
(11.4)\end{array}$ & $\begin{array}{c}13 \\
(13.8)\end{array}$ & $\begin{array}{c}17 \\
(13.2)\end{array}$ \\
\hline $\begin{array}{l}\text { 10. Role capable of } \\
\text { adjusting opinions with } \\
\text { other group }\end{array}$ & $0(0)$ & $1(1.1)$ & $1(0.8)$ \\
\hline $\begin{array}{l}\text { 11. Role satisfying } \\
\text { emotion through products }\end{array}$ & $1(2.9)$ & $\begin{array}{c}11 \\
(11.7)\end{array}$ & $\begin{array}{c}12 \\
(9.3)\end{array}$ \\
\hline $\begin{array}{l}\text { 12. Role standardizing } \\
\text { ideas }\end{array}$ & $3(8.6)$ & $5(5.3)$ & $8(6.2)$ \\
\hline $\begin{array}{l}\text { 13. Role improving } \\
\text { quality }\end{array}$ & $0(0)$ & $5(5.3)$ & $5(3.9)$ \\
\hline total & $\begin{array}{c}35 \\
(100)\end{array}$ & $\begin{array}{c}94 \\
(100)\end{array}$ & $\begin{array}{c}129 \\
(100)\end{array}$ \\
\hline Test Statistic & \multicolumn{2}{|c|}{$y^{2}=27.342, p=0.007$} & \\
\hline
\end{tabular}

\section{CONCLUSION}

\section{1 research results}

Questions on 'what role should a designer do at a corporate organization?' are repetitively and continuously questioned by many designers for last several years and various answers are coming out. Why does it appear? This research generalizes not only the studies on role of a designer, but also produced a result of re-definition on 'role definition of designers' in various dimensions by surveying current design recognition of incumbent persons responsible for design practice. Research results newly created through this research are as follows. First, 13 kinds of 'definitions on a role of designer at a company' were deduced through field survey of incumbent presidents and persons who are responsible for the practical design in design- 
specialized companies. Second, as a result of recognition survey on a designer's role at a company, a designer group is thinking that "a medium role connecting a company to consumers" and "a role leading culture" are the most important. A design job-related group and non-designers pointed out that "a role creating vision of a company through product design" as the most important role of a designer. Third, there is no difference in recognition about 'a role of a designer at a company' between a design job-related group and a nondesigner group in this research. In this research, the design jobrelated group and a non-designer group can be largely said a non-designer group. As a result of analyzing difference of recognition on designer's role between designer and nondesigner groups, it was surveyed that there is a clear difference in 'recognition on a designer's role at a company' between two groups. Fourth, the typical difference items among differences of recognition on designer's role between a designer group and non-designer group are as follows. Designers are showing low consensus on a role of designer that is the "It generally means an intention or design of human beings.", "what do design is a process giving visual sense, namely, a meaning to an image" and "putting on beauty to products", but it appeared that nondesigners showed high consensus. On the other hand, it was surveyed that non-designers sympathize on the design recognition that design is "what raises a life value of human beings" and is "what connects an idea to skills" more than designers. Lastly, designers were forming more consensuses on "a role making appearance attractively" and "a medium role which is connecting a company to consumers" about a designer's role at a company than non-designers. And nondesigners were recognizing "a role creating a new value based on capacity of a company" more important than designers as a role of a designer.

\section{2 values and meaning of the research results}

Design decision making in design development process is mostly achieved together with designers, marketers, engineers and especially, highest responsible persons for product development like a president. However, it would never be easy to make decision with a designer and the other specialists who are having different basic recognition on what role of a designer should do at a corporate organization in design development process. In this viewpoint, this research will give a help in making more developing design decision amid understanding and sympathy on designer's role of many people by investigating difference between designers and nondesigners comprehensively. As the other meaningful result, this research also gathered and produced overall definition of designer's role in the company by many scholars and the design industry sporadically put out in the meanwhile.

\section{REFERENCES}

[1] Lee Il-Gyu, "Road standing high as Design Power", Joongang Ilbo, April 09, 2007.

[2] Kim Eo-Jun, Play for your good fight, Green Forest, 2008.

[3] R. B. Burns, "The self-conception:in theory, measurement, development, behavior", New York,
Longman, p.51.

[4] Olson E. M, "Perceptual Differences in interdependence, conflict, and conflict resolution between design and other functions involved in new product development", Fifth international forum on design management research and education, July14-16, MIT, p 1

[5] Michael Brassard \& Diane Ritter, The Memory Jogger 2, A Pocket guide of tools for continuous improvement \& effective planning, GOAL/QPC, 1994, pp.12-13.

[6] Michael Brassard \& Diane Ritter, The Memory Jogger 2, A Pocket guide of tools for continuous improvement \& effective planning, GOAL/QPC, 1994, pp.14-18.

[7] Hopkins D. S., "New product winners and losers, Research Management”, Vol. 24, No. 3, pp.12-17,1981.

[8] Cooper R. \& Press M., "The Design Agenda: A guide of successful design management", Chichester, John Wiley \& Sons Ltd, 1995, pp149-150.

[9] Walsh V., Roy R., Bruce M. and Potter S., Winning by design, U.K, Blackwell published, fall, 1993.

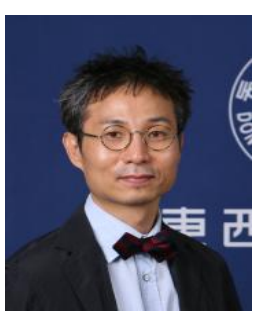

Kang, Bum-Kyu

He received the B.S., M.S in Industrial Design from Kon-Kuk University, Korea in 1993, 1996 respectively and also received M.A. in DeMontford University in England. He also got a Ph.D. in Design Management from Buruel University, England in 2002. Since then, he works in Design Department of Dongseo University as a professor. He is not only a president in DIDIC (Digital Image Design Innovation Center), but also a director in BK21 team which is sponsored by Korea government. His main research interests in the industrial design, design management and design value, etc,. 